\title{
SILVICULTURE AND UTILIZATION
}

by A. BiCKERSTAFF

\author{
Dominion Forest Service, Ottawa, Ontario
}

The word silviculture is often used as a synonym for all phases of technical forestry which are practised in countries other than Canada. It is also used as an omnibus word to describe all operations in the forest which will some day, in some miraculous manner, bring about greatly increased yields per acre, and at the same time bring about sustained yield quite painlessly. Unfortunately silviculture does not, and cannot, work such miracles without a little outside assistance. All that silviculture attempts to do is to get the right species established on the right site, and see to it that they continue to grow at their optimum rate.

Yields per acre can only be increased in two ways. The yield can be increased up to a certain point by ensuring that there is a sufficient number of trees per acre to utilize the site. Since many of our forest areas are understocked this method of increasing the yield offers very definite possibilities. However, when a stand is well stocked, silviculture can do very little to appreciably increase the yield. Any major increase in the yield of fully stocked stands must be brought about by utilizing the trees which are growing in the stand. This is a very important point which will bear emphasis. The amount of wood which an adequately stocked stand produces annually cannot be appreciably increased by any silvicultural magic. The only way to increase the yield from such an area is to use all the wood which the forest will produce. When all the wood which an area produces is utilized, the increase in yield is tremendous. The Ottawa Valley can be used as an example.

The Ottawa Valley could easily produce four times its present annual yield of wood fibre, and it could continue to do so without any increase in the growth, and with only rudimentary silviculture applied with a reasonable amount of common-sense. The major requirement is good utilization, or, integrated utilization if you wish to call it that. Four times the present yield sounds fantastic, but it does not require very much arithmetic to arrive at such a figure. It is based on this reasoning: at a conservative estimate, at least one-half of the standing timber of the Ottawa Valley is low grade hardwood, of which only a negligible amount is now being used. Use this low grade hardwood and the yield of the area is doubled. Assuming that the low grade material is utilized, where does the remainder of this increased yield come from? That is simple too. Most European yield tables based on managed stands which have been thinned at short intervals throughout the rotation indicate that the sum total of all the thinnings is approximately equal to the amount of timber which is standing at the end of the rotation. In other words every stand of timber produces during its lifetime about twice as much wood fibre as that which is standing at maturity; up to one-half of the potential yield is lost from mortality if no cutting is made in the stands before they are mature. It is a question of use it, or, lose it.

1 Paper presented at a joint meeting of the Ottawa Valley and Quebec Sections, C.S.F.E., Ottawn, May 12th, 1949. 
The art of silviculture was developed to meet the demands of utilization. It developed in Europe because there was a scarcity of wood. For example, thinnings were made to get wood out of the forest before the stands were mature. They were not made to beautify the forest or because government regulations said they had to be made. In fact some regulations made by the state were to prevent too much wood being removed by thinnings. Similarly, various methods of harvest cutting were developed because it was economically essential to have a new stand to replace the stand which had been cut, or in mixed stands to utilize each species as it matured. Harvest cutting methods were not developed to give employment to silviculturists or to give mental exercise to students of forestry, they were developed because the country had to have wood. Silviculture only becomes of age when utilization is good and the demand for wood is great. It is not an end in itself.

However, that does not mean that silviculture is unimportant. Canadian silviculture, in conjunction with realistic methods of utilization could make the European "text-book type" of forest management a reality instead of something which we merely admire and talk about. The methods of silviculture which we were taught in school were developed in an economy where pulpwood and chemical wood were unknown; fuelwood and sawlogs were practically the only products. At the present time it is economically feasible to use practically every tree which the forest will produce for some product with a higher unit value than fuelwood. While this is possible, very few companies are equipped to handle the wood which is growing on their limits. The procedure has also invariably been to set up a mill which can utilize only a small portion of the wood fibre which the limits can produce. Major progress in integrated utilization has been at the mill, not in the forest. Methods have been developed to profitably manufacture products from sawdust, slabs and edgings, bark and waste liquors or practically everything that has been taken out of the forest. But there has been very little progress in utilizing the waste material in the forest. By waste material in the forest I do not mean the stumps and branches, although perhaps some day even these may be used; but rather the trees which are not cut, because they are defective, are of undesirable species, or are under size. Trees in this class are the trees which can quadruple the average yields per acre, and they are the trees which must be removed to put the forest in a good silvicultural condition.

In some cases this is already done. When black spruce stands are clearcut to $4^{\prime \prime}$ D.B.H., utilization is almost perfect and the stands are usually satisfactorily regenerated and in good silvicultural condition. In mixed stands of spruce and hardwoods, the picture is not nearly so bright. Yield per acre of conifers is low and logging costs are higher. Hardwoods of sawlog or veneer quality may be cut, or perhaps the poplar pulp is cut on a small part of the area, but generally all the hardwoods plus the cull conifers are left to clutter up the area. If any means can be devised to use this material, the immediate yields per acre can be doubled and still leave the stands in better silvicultural condition than they were before cutting. Silviculture can 
do almost nothing to improve such stands unless there is better utilization of the cull trees and the so-called unmerchantable species.

Popular opinion to the contrary, good silviculture often requires the cutting of small trees. There are two reasons for this. The most practical reason is that if some of them are not cut they will eventually die and be a complete loss. The other is that the production of wood fibre which is being spread over a large number of small trees can often be profitably transferred to a smaller number of trees. That is, when the trees on an area fully occupy the site, the area tends to produce approximately the same amount of wood fibre regardless of how many trees per acre there are on it. If the number of trees is comparatively small, more wood is added to each tree, although naturally there is a point of diminishing returns.

From my remarks you may have obtained the impression that $I$ am advocating clear-cutting and utter devastation of the forest so that the last possible cubic foot of wood can be taken off an area. Nothing could be farther from the truth. I merely wish to make the point that it must be possible to utilize everything that the forest will grow in order to have the ultimate in silviculture. Whether or not certain material should be utilized at a certain time, must depend upon the silvicultural requirements and characteristics of the stand in question. For instance, when a jack pine stand is cut for sawlogs or ties, all of the undersize material could be used for pulpwood or pitprops since it will in all probability blow down within a few years and never develop into sawlogs. At the other extreme, consider a stand of mature and overmature tolerant hardwoods which is being cut for sawlogs. The usual practice is to cut everything which is merchantable down to a diameter limit normally set by market conditions. Defective trees and undersize trees are not cut. From a silvicultural viewpoint and to obtain the maximum future production of wood from the stand, the best cutting practice would be to cut not more than perhaps one-third of the volume of the stand, with the volume made up first of overmature and defective trees, next of sound trees at or near maturity, and then of thinnings from the smaller trees. If such a stand were cut in the suggested manner for the jack pine stand, the result might be a good raspberry patch, whereas under the conventional system of logging it would be neither a good raspberry patch nor a good stand of timber. Utilization in any stand must be geared to the silvicultural requirements of the stand. Since the silvicultural requirements change from stand to stand, utilization must be flexible if the greatest yield is to be obtained from any area.

One aspect of utilization which has a profound influence upon silviculture and on forest regulation, is what material will be used twenty years from now, or in fifty years? Will mills generally accept all types of wood fibre or will the hardwoods still be rotting on the stump? The answer to that question is of more than academic interest. If the productive capacity of the forest can be utilized in the not too distant future, cutting budgets can be increased not only at some future date, but right now. In addition, many silvicultural problems which at present appear insurmountable cease to exist. Most pulp 
and paper companies in Eastern Canada are still living off their forest capital of mature and overmature softwood stands. Hardwood stands are of no importance in the cutting budget. For sustained yield on these limits the old stands must last until cut-over stands, or other areas of young coniferous growth, are ready for cutting. If hardwoods of all species could be utilized efficiently for pulp or chemical products in say twenty years' time, the existing stands of overmature softwoods could be liquidated at a greatly accelerated rate without any fear of leaving the mill without wood or of having to cut immature stands. The silvicultural paradox of trying to make hardwood areas produce good stands of conifers would also disappear.

To sum up I would express the opinion that the greatest progress in silviculture, and in our forest economy generally, will come by devising ways and means of using what the forests are producing rather than silviculture trying to make the forest produce what we happen to need at the moment. More progress has been made in utilization in the past 40 years than has been made in silviculture in the past 400 years. A finished product can be made from a tree in a few minutes or a few hours, but it takes almost 100 years to grow the tree. Methods of utilization can change rapidly, but I cannot see much hope of changing our forests overnight. It is just as logical to expect a hydraulic engineer to make water run up-hill of its own accord as to hope that silviculture will be able to meet the needs of the mill by changing the biological laws which govern the growth of the forest. Silviculture can establish the right trees on the right sites and can maintain optimum growing conditions so that each acre will produce at its maximum, but silviculture cannot make trees grow on sites where they do not want to grow, and cannot maintain the forest as an efficient producer of wood fibre unless the material produced by the forest can be removed.

In the past the forest has been the whipping boy for the mill: when the mill becomes the handmaiden of the forest, we will have good silviculture and truly integrated utilization. 